\title{
Должсанская Татьяна Юрьевна
}

канд. геол.-минерал. наук, старший преподаватель

ФГБОУ ВО «Российский государственный геолого-разведочный университет имени Серго Орджоникидзе»

г. Москва

DOI $10.31483 / r-97328$

\section{ПРОЕКТ «УНИВЕРСИТЕТСКИЕ СУББОТЫ» КАК ОДИН ИЗ МЕТОДОВ ПОПУЛЯРИЗАЦИИ ЕСТЕСТВЕННОНАУЧНОГО НАПРАВЛЕНИЯ В ПРОФОРИЕНТАЦИОННОЙ ДЕЯТЕЛЬНОСТИ МИНЕРАЛОГИЧЕСКОГО МУЗЕЯ МГРИ}

Аннотация: статья посвящена разнообразным формам профориентационной работы со школьниками Минералогического музея Российского государственного геологоразведочного университета им. С. Орджоникидзе (МГРИ). Просветительские мероприятия, в том числе, и по проекту «Университетские субботы», проходят на площадках Музея в виде экскурсий, мастер-классов с показом методик диагностики минералов, а также в форме выездных детских геологических экспедищий и «уроков на природе». Все это приобщает учащихся к профессии, создаёт условия для ранней предметной ориентации, повымает качество довузовской подготовки и уровень образовательной мотивации школьников.

Ключевые слова: проект «Университетские субботы», профориентация, дополнительное образование, музейная педагогика, первичные компетенции, детско-юноческое геологическое движение, юный геолог.

В последние годы в Российском образовании, как известно, проходят интенсивные процессы модернизации системы общего и профессионального образования, направленные на изменения качества самого образовательного процесса и более тесной связи высшей и средней школ. Всё больше и больше различных проектов, связанных с дополнительным образованием и профориентацией, инициируется на государственном и региональном уровнях [10]. 
Все эти мероприятия направлены на усиление внимания к процессам вхождения выпускников в рынки труда и образования, к стартовым этапам профессиональной карьеры, что обуславливает потребность в развитии профессионального самоопределения школьников. Дополнительное, подчас узко тематическое, образование и профориентационные мероприятия помогают ученику не только определиться с будущей специальностью, но и подготовить его к избранному пути, сформировать первичные компетенции для вхождения в выбранную профессию.

Именно поэтому приоритетным направлением работы со школьниками Минералогического музея Российского государственного геологоразведочного университета им. Серго Орджоникидзе (МГРИ) является концепция долгосрочной, пролонгированной социально-профессиональной подготовки учащихся, целенаправленное развитие способностей к жизненному и профессиональному самоопределению, а также информационно-просветительская и социальная поддержка детей и школьников, в том числе, детей с проблемами здоровья, их педагогов и семей.

В течение последних полутора десятилетий сотрудники Минералогического музея реализуют широкий спектр профориентационных и тематических проектов для учащихся всех уровней, общей идеей которых является предоставление возможности широкой детской и школьной аудитории прикоснуться к новому для них миру науки на примере демонстрации и изучения естественнонаучных и природных объектов внутри и вне музейного пространства.

Безусловно, наш опыт возник не на «пустом месте»: в целом, минералогическая школа МГРИ имеет более 300-летюю историю преподавания дисциплин минералогического цикла; сотрудники Музея обладают многолетним опытом экскурсионной и педагогической деятельности, организации учебных полевых практик студентов, выездных школьных геологических экспедиций; мы участвуем в организации работы и ведении занятий для школьников на Школьном факультете МГРИ, а также в разработке оценочных критериев и рецензировании 
работ учащихся и команд на Всероссийских и региональных Олимпиадах по геологии в рамках Детско-юношеского геологического движения России $[3,8]$.

Профориентационные проекты Минералогического музея направлены на популяризацию естественнонаучной области знаний, на знакомство широкой детской аудитории с науками о Земле. В связи с этим, в Музее сформирован целый блок популярных программ, по которым осуществляется ряд проектов «Нескучный музей» (2007 - 2019 гг.), «Университетские субботы» (2013 - 2020 гг.), «Музей вызывали?» (2006 - 2019 гг.), «Уроки на природе» (2008 - 2020 гг.); работает кружок для младших и старших школьников с еженедельными занятиями, в том числе, и в дистанционной форме.

Нужно отметить, что Минералогический музей МГРИ одним из первых внутривузовских музеев города Москвы включился в общегородской проект «Университетские субботы» (позже «Субботы московского школьника»), который был инициирован Департаментом образования г. Москвы и стартовал в сентябре 2013 г. Уже 7 сентября 2013 г. в нашем Музее состоялась первое заседание по проекту «Университетские субботы», посвященное минералам Москвы и Подмосковья, и приурочено ко Дню Города Москвы. Как обычно, экскурсия и организованный в конце мероприятия мастер-класс носили не только познавательный характер, это был «живой» рассказ профессионалов о своей профессии с культурным и историческим экскурсом в архитектуру любимого города, с использованием методов визуализации пространства музея и, конечно, краеведческим компонентом.

Формы работы с учащимися во всех проектах Музея, и также в проекте «Университетские субботы», весьма разнообразны. Основным лейб-мотивом всех мероприятий является яркое, запоминающееся и интересное представление объектов природы и даже сложных явлений, происходящих на нашей планете, которое преподносится простым и понятным детям языком. В нашей профориентационной работе используются традиционные экскурсии, в которых знакомство с музейными экспозициями осуществляется по принципу «нескучный музей». Здесь важно сочетание лекционно-теоретической формы подачи материала 
с возможностью прикоснуться к интересующим образцам. Это позволяют сделать крупные экспонаты, расположенные на доступных подиумах.

Большой отклик о полученных впечатлениях и первых навыках профессиональной работы, конечно, получают проводимые нами мастер-классы или лабораторные работы по программе «Минералог-эксперт». Здесь особенно тесно проявляется контакт ведущего со зрителем, классом, кружком, отдельным школьником, в том числе, и детьми с ограниченными возможностями. Увлекательное представление минералогического инструментария и опытов по диагностики разных свойств минералов, порой театрализованное, или показанное в виде «минералогических фокусов», вызывает неподдельный интерес не только у детей, но и у старшеклассников, учащихся колледжей, педагогов, родителей.

Большое внимание уделяется выездной форме профориентационных услуг. Выставки образцов, тематические уроки и мастер-класс сотрудники Музея проводят в общеобразовательных школах гор. Москвы, в детских диагностических и реабилитационных центрах, клубах, домах творчества школьников, в библиотеках, на других образовательных площадках. Выставочные проекты и мастерклассы были организованы, например, в Детском Центре Нейропсихологии на территории ЮЗАО гор. Москвы, в «Аптекарском огороде» Биологического факультета МГУ, в детских домах-интернатах.

Естественно, современная эпидемиологическая ситуация внесла коррективы и в наше расписание. С 20 марта 2020 года практически все экскурсии, занятия и мастер-классы по проекту «Университетские субботы» и другие массовые мероприятия со школьниками, Олимпиада, фестивали, заседания кружка, популярные лекции «Минералогический университет» и пр. стали проходить в дистанционном формате при помощи телекоммуникационных систем Zoom, Skype, Team. Впрочем, «удалённая» форма занятий по минералогической тематике, которая ведётся прямо из залов Минералогического музея, нисколько не снизила интереса учащихся. Однозначно, посещаемость многих мероприятий выросла в 3-5 раз. Дистанционная форма позволила охватить тех школьников, которые «не успевали» зарегистрироваться на наши занятия, так как количество 
экскурсантов и мест в зале для мастер-классов всегда ограничено 25 - 30 посетителями. Яркие презентации, логичное построение предлагаемого материала, уникальные демонстрируемые образцы минералов, доступное изложение, артистизм и обаяние самого ведущего сделали мероприятия долгожданными для школьников, снискали даже постоянных участников наших мероприятий, в числе которых целые классы, например, из школы «26 кард» ЮЗАО гор. Москвы.

Нужно отметить, что наши профориентационные занятия проходят не только на площадке музея МГРИ, среди витрин, пусть и с уникальными образцами минералов и горных пород. Минералогия - наука естественная, изучающая самые удивительные явления природы - минералы, и поэтому приобщение детей и молодежной аудитории к раннему познанию и пониманию природы, демонстрация особенностей профессии геолога, невозможно только в аудитории. Необходимы экскурсии, походы, поездки, экспедиции, полевые практикумы и маршруты в различные «геологические уголки». В проекте «Университетские субботы» 2013 - 2015 годов, а в настоящее время в рамках работы школьного кружка проводятся выездные мероприятия по программе «В каникулы за минералами» и «Уроки на природе». Это различные однодневные маршруты и экскурсии по Москве и Подмосковью, которые затрагивают вопросы истории города, подмосковных городков, размещения исторических зданий, описание геологических памятников Подмосковья, изучение мест добычи «белого камня», составление отчёта о своей работе.

Для школьных геологических и экологических кружков и клубов в рамке подготовке к всероссийским и региональным Олимпиадам и конкурсам сотрудниками Минералогического музея организуются полевые геологические Школы (они неоднократно проходили в Карелии, в Крыму, в Подмосковье). Эти «полевые уроки» настраивают школьников на настоящую полевую работу; ребята, приобретая простые навыки описания природных объектов, приобщаются к условиям работы геолога, начинают понимать общую последовательность в подготовке самостоятельной исследовательской работы (от описательного этапа, 
лабораторных исследований, знакомства с литературой до составления отчёта и формирования выставок собранных образцов).

Хочу ещё раз отметить, что многократность (повторяемость) общего плана лекций, экскурсий, занятий, мастер-классов и полевых маршрутов не отменяет изменчивости форм проведения мероприятий и их места. Так из нашего многолетнего опыта проведения профориентационных занятий со школьниками появился масштабный образовательный проект «ГеоАртек», который проводится с 2017 года МГРИ и ООО «Росгеология» совместно с МЦД «Артек» и на площадке одного из лагерей. «ГеоАртек» стал своеобразной инновационной формой опережающей подготовки юных геологов со всей страны. Занятия и маршруты в течение одной смены (21 день) знакомят школьников с основами профессии геолога с макетами, коллекциями минералов, оптическими и геофизическими приборами, сложным буровым оборудованием явилось формирование у школьников интереса к наукам о Земле, воспитание экологической культуры и популяризации профессии геолога. В мероприятиях «ГеоАртек» каждый год принимают участие более 300 школьников в возрасте от 10 до 17 лет почти из трети регионов России [5].

Наши занятия и экскурсии, походы и экспедиции - это незабываемые часы, посвященные формированию маленькой личности, с устойчивым ранним профессиональным интересом, верностью полученным нравственным ориентирам и сформированным природно-эстетическим кругозором. Выработанная и многократно опробованная методика занятий и мастер-классов в музейном пространстве или в период «полевых практик», одновременно дает не только профориентационный эффект, сама геологическая среда и природа создаёт возможность современным детям оторваться от «компьютерной виртуальной реальности», стать, пусть ненадолго, членами одной команды, самостоятельно принимающими решения, способными мыслить и анализировать, отвечать за себя вдали от «мам и пап».

Итак, профориентационные и просветительские проекты Минералогического музея МГРИ - уникальная коммуникационная площадка для развития 
непрерывной системы образования в области природопользования. Они позволяют повысить качество довузовской подготовки и уровень образовательной мотивации школьников; направлены на формирование и воспитание подрастающего поколения, поколения, способного исследовать, творить, принимать решения; поколения, способного поддерживать и приумножать сырьевую базу нашей страны.

\section{Сиисок литературы}

1. Андреева Л.И. Профориентационное определение школьников в условиях инновационной деятельности общеобразовательного учреждения: автореф. дис. ... д-ра пед. наук. - Тольятти, ТГУ, 2010.

2. Асафова Т.Ф. Развитие социального творчества в системе дополнительного образования как инструмент подготовки детей к будущей успешной жизни // Внешкольник. - 2018. - №3.

3. Белов С.В. Концептуальная модель детско-юношеского геологического движения в России / С.В. Белов, Н.В. Трусова [и др.]. - М.: Геоинформмарк, 2001.

4. Вайндорф-Сысоева М.Е. Методика дистанционного обучения: учебное пособие для вузов / М.Е. Вайндорф-Сысоева, Т.С. Грязнова, В.А. Шитова. - М., Юрайт, 2018. - 194 с.

5. Верчеба А.А. Профессиональные образовательные геологические мероприятия во внеаудиторное время / А.А. Верчеба, Т.Ю. Должанская // Тезисы доклада. 14-ая науч.-практ. конференция «Новые идеи в науках о Земле». - М.: МГРИ, 2019.

6. Дзагоева Е.А. Геологический туризм в дополнительном образовании школьников // Известия АО РГО. - 2015. - №1 (36).

7. Должанская Т.Ю. Минералы. Энциклопедия для детей. - М.: РОСМЭН, 2019.

8. Дополнительное образование детей по геологии и минеральным ресурсам. - М.: Геоинформмарк, 2001. 
9. Зебзеева В.А. Развитие элементарных естественнонаучных представлений и экологической культуры детей: учебное пособие. - М.: Сфера, 2009.

10. Законодательство в образовании: сборник основных нормативно-правовых документов в области образования. - М.: Современный гуманитарный университет, 2019. - 161 с.

11. Фролова М.С. Учёба в сети: как дистанционное обучение прижилось в главном геологоразведочном вузе страны? [Электронный ресурс]. - Режим доступа: zen/yandex.ru (дата обращения: 18.11.2020).

12. Штерингарц Е.М. Детский научный клуб. Организация развивающего обучения школьников в дополнительном образовании / Е.М. Штерингарц. - М.: Авторский Клуб, 2015. 